\title{
Indian Hedgehog Protein Levels in Autistic Children: Preliminary Results
}

\section{Shahid Bashir ${ }^{1,2 *}$ and Laila AL-Ayadhi ${ }^{2}$}

${ }^{1}$ Berenson-Allen Center for Noninvasive Brain Stimulation, Division of Cognitive Neurology, Department of Neurology, Beth Israel Deaconess Medical Center, Harvard Medical School, Boston, MA, USA

${ }^{2}$ KSU-Autism Research and Treatment center, Al-Amodi Autism research chair, Department of physiology, King Saud University, P O Box 2925, Riyadh 11461, Saudi

Arabia

\begin{abstract}
The etiology of autism spectrum disorders (ASD) is not well known but recently we reported that the serum levels of sonic hedgehog (SHH) protein and brain-derived neurotrophic factor (BDNF) might be linked to oxidative stress in ASD. We hypothesized that Indian hedgehog $(\mathrm{IHH})$ protein which belongs to SHH family may play a pathological role in the ASD. We studied recently diagnosed patients in early stages of ASD $(n=54)$ and age-matched, cognitively normal, individuals $(n=25)$, using serum levels of $\mathrm{IHH}$ protein. We found statistically significantly higher-levels of serum IHH protein in ASD subjects $(p=0.001)$ compared to control subjects. Our findings are the first to report a role of IHH in ASD children, suggesting a possible pathological role-played by IHH in early-stage in ASD. Such measures might constitute an early biomarker for ASD and ultimately offer a target for novel biomarker-based therapeutic interventions.
\end{abstract}

Keywords: Autism spectrum disorder; Indian hedgehog; Biomarker

\section{Introduction}

The incidence of Autism spectrum disorders (ASD) has been increased during the last decade to about $1 / 100$ children with a maleto-female ratio of four to one (4:1) [1]. Despite the fact that there is an increase in autism research worldwide, exact etiology of autism and ASD remains largely unknown $[2,3]$. We reported recently that the serum levels of sonic hedgehog $(\mathrm{SHH})$ protein and brain-derived neurotrophic factor (BDNF) might be linked to oxidative stress in ASD [4]. Indian hedgehog ( $\mathrm{IHH})$ and the sonic hedgehog $(\mathrm{SHH})$ protein from the Hedgehog family. IHH seems to play at least two roles in vertebrate development. The first role of IHH appears to be critical for the differentiation of the visceral endoderm [3], and to regulate the proliferation and differentiation of the gut epithelial stem cell [5]. It appears that in the development of the gut, both sonic hedgehog and IHH are needed and many target genes that control cell growth, survival, and differentiation in a wide variety of cells, including neurons [6]. These are signaling proteins from the Hedgehog family. Research studies have shown that hedgehog signaling is activated in adult organism after injury and is involved in tissue repair mechanisms $[6,7]$. Thus the aim of the current study was to explore a possible role of IHH protein in children with ASD.

\section{Methods \\ Participants}

Fifty-four children with ASD were recruited in the study (mean age: $6 \pm 1.72$ years; age-range: $3-11$ years, 51 males and 3 females) and 25 age- and sex- matched healthy children $(7.04 \pm 1.74 ; 3-11,23$ males and 2 females) served as the control group. The diagnosis of ASD was made by child neurophysiologist, and pediatrician based on the criteria of ASD as defined in the Diagnostic and Statistical Manual of Mental Disorders, Fourth (DSM-IV) [2] on the day of screening test. The Childhood Autism Rating Scale (CARS) was completed as a further measurement of the severity of ASD which rates the child on a scale from one to four in each of fifteen areas (relating to people; emotional response; imitation; body use; object use; listening response; fear or nervousness; verbal communication; non-verbal communication; activity level; level and reliability of intellectual response; adaptation to change; visual response; taste, smell and touch response and general impressions). According to the scale, children who have scored 30-36 have mild to moderate autism $(\mathrm{n}=24)$, while those with scores ranging between 37 and 60 points have severe autism $(\mathrm{n}=31)$. Complete diagnostic work-ups including medical, neurological, psychiatric, and psychological evaluations were done for all of the subjects. None of the participants had neurological disorders (seizure, traumatic brain injury, brain tumor). Written informed consent was obtained from all participants (parents/guardian) prior to entering the study, which had been reviewed and approved by the local Institutional Review Boards. All procedures followed were in accordance with the Helsinki Declaration.

\section{Study Procedure}

\section{Blood samples}

After an overnight fasting, blood samples $(3 \mathrm{ml})$ were collected from subjects in both groups in plain test tubes. Blood samples were centrifuged at 3,000 rpm to collect serum samples, which were stored frozen in a freezer at $-80^{\circ} \mathrm{C}$ until the time of analytical assays.

\section{Indian hedgehog (IHH) assay}

Serum level of IHH was measured using a commercially available sandwich enzyme immunoassay (ELISA) kit from CUSABIO BIOTECH CO. Ltd (Wuhan, China). The detail description of the procedure has been described in our previous report [4]. No significant cross-reactivity or interference was observed. To increase accuracy, all samples were analyzed twice in two independent experiments to assess

\footnotetext{
*Corresponding author: Shahid Bashir, KSU-Autism Research and Treatment center, Al-Amodi Autism research chair, Department of physiology, King Saud University, Saudi Arabia, Tel: T:00966-46-71040; Fax: T:00966-46-71040; E-mail: sbashir10@gmail.com

Received September 26, 2012; Accepted October 25, 2012; Published October 29, 2012

Citation: Bashir S, AL-Ayadhi L (2012) Indian Hedgehog Protein Levels in Autistic Children: Preliminary Results. J Mol Biomark Diagn 3:134. doi:10.4172/21559929.1000134

Copyright: (C) 2012 Bashir S, et al. This is an open-access article distributed under the terms of the Creative Commons Attribution License, which permits unrestricted use, distribution, and reproduction in any medium, provided the original author and source are credited
} 
Citation: Bashir S, AL-Ayadhi L (2012) Indian Hedgehog Protein Levels in Autistic Children: Preliminary Results. J Mol Biomark Diagn 3:134. doi:10.4172/2155-9929.1000134

Page 2 of 3

inter-assay variations and to ensure reproducibility of the observed results $(\mathrm{P}>0.05)$.

\section{Statistical analysis}

Metabolic data are presented as mean \pm standard deviation (SD). Statistical differences were ascertained by using the Student's $t$ test with significance set at a $\mathrm{P}$ value of 0.05 or lower. The relationships between IHH levels and CARS among patients with autism were evaluated by computing Pearson's correlation coefficients.

\section{Results}

Serum levels of Indian hedgehog $(\mathrm{IHH})$ were significantly higher in ASD patients compared to healthy controls group ( $\mathrm{p}=0.001$; Figure 1; Table 1). Specifically the serum IHH level in the subjects with ASD was $1.63 \pm 0.131(\mathrm{pg} / \mathrm{ml})$ as compared to $0.79 \pm 0.109(\mathrm{pg} / \mathrm{ml})$ in the controls (Table 1) group. Higher plasma IHH levels were found in 67\% (37/54) of ASD children compared to mean value of ASD. Serum IHH levels of autistic subjects had no significant correlations with CARS scoring $(\mathrm{P}=0.870)$. Furthermore, Serum IHH levels of autistic subject had no significant correlations with the age of autistic subjects $(\mathrm{P}=0.64)$.

\section{Discussion}

Our findings demonstrate significantly higher levels of Indian hedgehog proteins (IHH), in subjects with ASD. Therefore, our results suggest abnormal IHH protein levels in ASD as compared with agematched controls.

The Indian Hedgehog protein is one of three proteins in the mammalian hedgehog family; IHH is involved in chondrocyte differentiation, proliferation and maturation especially during endochondral ossification [3,5]. It regulates its effects by feedback control of parathyroid hormone-related peptide (PTHrP) [8].

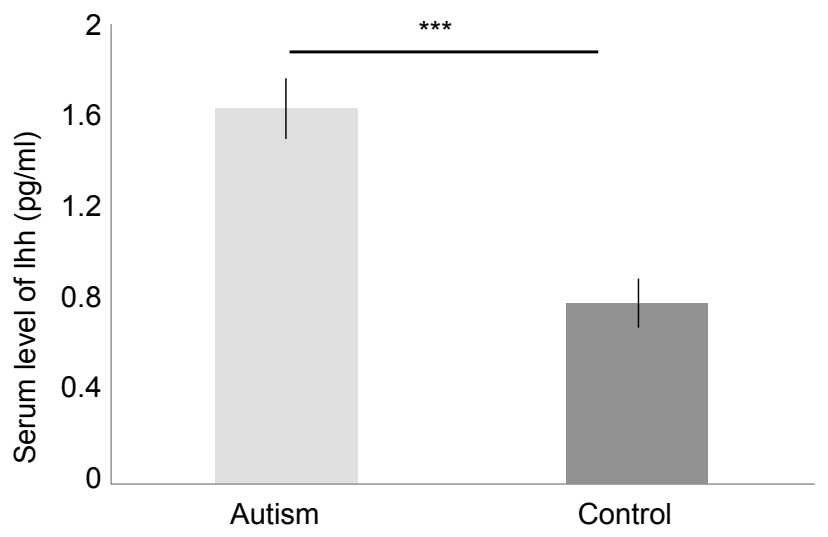

Figure 1: Serum levels of Indian hedgehog protein in control and autistic children. Highly statistically significant Indian hedgehog serum level in autism compared to control $(p=0.001)$.

\begin{tabular}{|l|l|l|}
\hline & $\begin{array}{l}\text { Indian hedgehog } \\
\text { Protein }(\mathbf{p g} / \mathbf{m l})\end{array}$ & P-value \\
\hline Healthy children $(\mathrm{n}=25)$ & $0.79 \pm 0.109$ & \\
\hline Patients with autism $(\mathrm{n}=55)$ & $1.63 \pm 0.131$ & $<0.001$ \\
\hline Patients with mild to moderate autism $(\mathrm{n}=24)$ & $1.41 \pm 0.179$ & \\
\hline Patients with severe autism $(\mathrm{n}=31)$ & $1.79 \pm 0.183$ & $<0.14$ \\
\hline
\end{tabular}

Table 1: Serum levels of Indian hedgehog protein in autistic children and their relation to the severity of autism.
Scientist demonstrated evidence related to hedgehog protein and involvement in the development and patterning of the central nervous system [6-11]. Human and animal disease model (Multiple Sclerosis Experimental Autoimmune Encepalomyelitis and cuprizone-induced demyelination) have shown elevated levels of hedgehog protein in the brain $[12,13]$. It points out towards a possible protective effect exerted by IHH and it is in agreement with our findings in autism. The roles of the hedgehog $(\mathrm{HH})$ signaling pathway in the CNS are gaining some interest lately, due to multifunctional properties of $\mathrm{HH}$, ranging from the regulation of new cells production to the modulation of neuronal electrophysiological activity [14].

It has been reported that activation of the Sonic hedgehog ( $\mathrm{SHH}$, belong to hedgehog family) pathway induces the increase of BDNF that may affect neuronal survival and differentiation. IHH is a morphogen important for the embryonic development. Possible correlation between BDNF and IHH is not studied. A recent study have shown causative relationship between the induction of $\mathrm{SHH}$ and BDNF [4]. Continuous administration of hedgehog inhibitor $\mathrm{CPM}$ to the injured site suppressed the increase of BDNF expression and, notably, deteriorated the survival of motor neurons in lumbar spinal cord [15]. In one scenario, IHH may act on a non-neuronal cell that in turn responds by secreting a neurotrophic factor. In another scenario, it is possible that IHH acts directly on some or all of the neurons, but the response is to secrete another factor(s) that actually possesses the survival activity. For example, IHH has been shown to induce the expression of TGF $\beta$ family members such as Bone morphogenetic proteins in vivo [16,17] and these proteins are trophic for midbrain dopaminergic neurons [16]. In the first case the factor is trophic for both dopaminergic and GABA-immunoreactive (GABAir) neurons. From the striatum, the surviving neurons are exclusively GABA-ir, whereas in the spinal cultures $\mathrm{HH}$ promotes survival of a heterogeneous population of putative interneurons. Metabolic stress induced by compromised mitochondria has been implicated in both acute and chronic neurodegenerative disorders such as ischemic stroke, Alzheimer's disease, Parkinson's disease (PD), and HD. Existing data provide support for considering IHH signaling as an important mechanism in tissue-repair process in brain diseases, and as a target for novel therapeutic approaches for the treatment of brain disorders and in particular ASD.

Our findings provide preliminary direct evidence of altered IHH protein in subject with ASD, which may contribute to the early pathogenesis of ASD offer valuable biomarkers and point to novel therapeutic interventions. However, given the small sample size, our results have to be considered preliminary and there may be patients who do not show such higher level of IHH in ASD. Hence, future studies with larger patient cohorts are warranted.

\section{References}

1. Vortkamp A, Lee K, Lanske B, Segre GV, Kronenberg HM, et al. (1996) Regulation of rate of cartilage differentiation by Indian hedgehog and PTHrelated protein. Science 273: 613-622.

2. American Psychiatric Association (2000) American psychiatric association, diagnostic and statistical manual-text revision (DSM-IV-TR TM). American Psychiatric Association, Washington, DC.

3. Fombonne E (2009) Epidemiology of pervasive developmental disorders Pediatr Res 65: 591-598.

4. Al-Ayadhi LY (2012) Relationship between Sonic Hedgehog Protein, BrainDerived Neurotrophic Factor and Oxidative Stress in Autism Spectrum Disorders. Neurochem Res 37: 394-400. 
Citation: Bashir S, AL-Ayadhi L (2012) Indian Hedgehog Protein Levels in Autistic Children: Preliminary Results. J Mol Biomark Diagn 3:134. doi:10.4172/2155-9929.1000134

Page 3 of 3

5. Laufer E, Nelson CE, Johnson RL, Morgan BA, Tabin C (1994) Sonic hedgehog and FGF-4 act through a signal cascade and feedback loop to integrate growth and patterning of the developing limb bud. Cell 79: 993-1003.

6. Mostafa GA, Al-Ayadhi LY (2011) Increased serum levels of anti-ganglioside M1 auto-antibodies in autistic children: relation to the disease severity. J Neuroinflammation 8: 39.

7. Hooper JE, Scott MP (2005) Communicating with hedgehogs. Nat Rev Mol Cell Biol 6: 306-317.

8. Levine JP, Bradley JP, Roth DA, McCarthy JG, Longaker MT (1995) Studies in cranial suture biology: regional dura mater determines overlying suture biology. Plast Surg Forum 18: 319-321.

9. Krieglstein K, Suter-Crazzolara C, Fischer WH, Unsicker K (1995) TGF-beta superfamily members promote survival of midbrain dopaminergic neurons and protect them against MPP+ toxicity. EMBO J 14: 736-742.

10. Harsan LA, Steibel J, Zaremba A, Agin A, Sapin R, et al. (2008) Recovery from chronic demyelination by thyroid hormone therapy: myelinogenesis induction and assessment by diffusion tensor magnetic resonance imaging. J Neurosci 28: 14189-14201.
11. Miao N, Wang M, Mahanthappa NK, Pang K (2006) Method of treating dopaminergic gaba-nergic disorders - EPO Patent EP1723950.

12. Riobo NA, Manning DR (2007) Pathways of signal transduction employed by vertebrate Hedgehogs. Biochem J 403: 369-379.

13. Hashimoto R, Moriguchi Y, Yamashita F, Mori T, Nemoto K, et al. (2008) Dose-dependent effect of the Val66Met polymorphism of the brain-derived neurotrophic factor gene on memory-related hippocampal activity. Neurosc Res 61: 360-367.

14. Banerjee SB, Rajendran R (2005) Recruitment of the sonic hedgehog signalling cascade in electroconvulsive seizure-mediated regulation of adult rat hippocampal neurogenesis. Eur J Neurosci 22: 1570-1580.

15. Pfaff SL, Mendelsohn M, Stewart CL, Edlund T, Jessel TM (1996) Requirement for LIM Homeobox Gene IsI 1 in Motor Neuron Generation Reveals a Moto Neuron-Dependent Step in Interneuron Differentiation. Cell 84: 309-320.

16. Theoharides TC, Doyle R, Francis K, Conti P, Kalogeromitros D (2008) Novel therapeutic targets for autism. Trends Pharmacol Sci 29: 375-382.

17. Seifert T, Bauer J, Weissert R, Fazekas F, Storch MK (2005) Differential expression of sonic hedgehog immunoreactivity during lesion evolution in autoimmune encephalomyelitis. J Neuropathol Exp Neurol 64: 404-411. 